\title{
EFFECT OF AMPICILLIN AND CHLORAMPHENICOL ON CHICK SERUM
}

\author{
HARSHIT NANDA, SUNEETHA V*
}

Department of Biotechnology, School of Biosciences and Technology, VIT University, Vellore - 632 014, Tamil Nadu, India.

Email: vsuneetha@vit.ac.in

Received: 17 April 2017, Revised and Accepted: 14 June 2017

ABSTRACT

Objective: Cystatin protein present in chick serum exhibits antimicrobial activity. The present study focuses on the effect of ampicillin and chloramphenicol antibiotics on chick serum and thus verifies Beer-Lambert's law.

Methods: The serum is separated from the cellular matter with the help of a micropipette to get a clean serum sample. The quantification of protein was done by Lowry's method. The antibiotics ampicillin and chloramphenicol stock solution were prepared by 10 mg of antibiotic powder in 10 ml of sterilized water. The statistical analysis of the values obtained was done by SPSS logistics software.

Results: The different values of concentration of serum with absorption showed a linear relationship which verifies Beer-Lambert's law. With an increase in the concentration of protein in chick serum, the absorption also increases, which gives a range of concentration of protein at which ampicillin and chloramphenicol act.

Conclusion: The rise and fall in the absorbance rate of proteins after addition of different antibiotics represent the increase and decrease in the concentration of proteins, respectively. This shows that every antibiotic acts at a particular concentration on the protein of the serum. Therefore, proper doses of antibiotics are recommended by the doctors.

Keywords: Spectrophotometry, Protein, Quantification, Bovine serum albumin, Serum.

(C) 2017 The Authors. Published by Innovare Academic Sciences Pvt Ltd. This is an open access article under the CC BY license (http://creativecommons. org/licenses/by/4. 0/) DOI: http://dx.doi.org/10.22159/ajpcr.2017.v10i10.19237

\section{INTRODUCTION}

Bovine serum albumin (BSA) is a transport protein found in serum which plays a major role in regulating the circulatory system in the human body [1]. It is a globular protein with 583 amino acids [2]. Its availability, feasibility, and ligand-binding properties give it uniqueness and it is easy to study the properties of the protein [3]. BSA is the most exuberant protein present in plasma [4]. It exhibits many similar features with human serum albumin [5].

Protein nanoparticles of BSA have several biomedical applications in drug delivery system and modifications [6]. The binding capacity of a drug to serum albumin present in human blood has momentous effect on metabolism of drugsthroughout thehumanbody [7].Several commercially prepared protein assay reagents are already available, and for our work, we have used the Lowry's reagent [8]. In the presence of protein, the reagent turns into blue - the concentration of protein present in the sample is directly proportional to the color produced. The blue-colored product absorbs light best at $750 \mathrm{~nm}$, and at this specific wavelength, we have done various measurements [9]. The protein quantification is determined by comparing the optical density values of the sample to the absorption coefficient obtained by plotting a standard curve. Lowry's reagent reacts equally with each type of protein, and hence it does not matter which protein is used for the process of quantification [10]. The silver nanoparticles synthesized in BSA matrix show antimicrobial [11] and antibacterial properties [12]. Chloramphenicol is effective against Gram-positive and Gram-negative bacteria [13] (Fig. 1).

Beer-Lambert's law states that there is a constant relationship between absorbance values and concentration of the sample; as the amount of concentration of protein increases, the absorbance value also increases. Thus, Beer-Lambert's law can only be applied when there is a linear relationship. Beer-Lambert's law is written as: $\mathrm{A}=\operatorname{epsilon}\{\mathrm{lc}\}$, where $\mathrm{A}$ is the measure of absorbance, $l$ is the path length, $c$ is the concentration, and Epsilon is the molar extinction coefficient or molar absorption or absorption coefficient. The law considers concentration of absorber as a constant value [14]. Cystatin protein in serum of chick has antimicrobial activity. Gram-negative strains such as Escherichia coli and Oligela sp. were more sensitive to lower concentration of cystatin than Gram-positive bacteria such as Staphylococcus aureus [15]. E. coli and Pseudomonas aeruginosa are substantially inhibited by cystatin even at low concentration [16].

\section{METHODS}

\section{Preparation of chick blood sample}

Chick blood sample was taken in a sterile tube and centrifuged at $4^{\circ} \mathrm{C}$ at $4000 \mathrm{rpm}$, for 10 minutes. Two distinct layers of serum and cellular matter were obtained and $5.5 \mathrm{ml}$ of Lowry's solution was added to each test tube. To mix the solutions properly, it was capped and vortexed briefly. The solution was incubated for 20 minutes at room temperature in dense light. At the last 5 minutes, the diluted form of Folin's reagent was prepared. After the process of incubation, prepared samples were taken and $0.5 \mathrm{ml}$ of diluted Folin's reagent was added to each test tube. The samples of BSA were transferred to a semi-micro disposable cuvette. Spectrophotometer was set in the quantitative mode and at $750 \mathrm{~nm}$. Then, the absorbance values for the standards at the standard mode and the samples at the unknown mode were recorded [17].

\section{Separation of serum from chick blood}

The serum was separated from the cellular matter with the help of micropipette to get a clean serum sample. Five test tubes were taken from the test tube stand and the three different concentrations of sample were added to the test tubes.

\section{Preparation of chemicals}

The chemicals used in our experimentwere Folin's reagent, sodium tartrate, copper sulfate, and two antibiotics - ampicillin and chloramphenicol. 
Preparation of solutions for characterization of protein

Using the individual solutions for the Lowry's solution, we prepared the solution and in particular mixed on the day of measurement and readings were taken from a spectrophotometer. $\mathrm{CuSO}_{4} \cdot 5 \mathrm{H}_{2} \mathrm{O}$ and $\mathrm{Na}_{2} \mathrm{C}_{4} \mathrm{H}_{4} \mathrm{O}_{6} \cdot 2 \mathrm{H}_{2} \mathrm{O}$ were dissolved separately in distilled water [18].

Solution A was prepared which is a dilute alkali solution [19].

- Solution A composition (alkaline solution of $500 \mathrm{ml}$ ): $2.8598 \mathrm{~g} \mathrm{NaOH}, 14.3084 \mathrm{~g} \mathrm{Na}_{2} \mathrm{CO}_{3}$

- Solution B composition (for $100 \mathrm{ml}$ ): $1.4232 \mathrm{~g} \mathrm{CUSO}_{4} \cdot 5 \mathrm{H}_{2} \mathrm{O}$

- Solution C composition (for $100 \mathrm{ml}$ ): $2.85299 \mathrm{~g} \mathrm{Na}_{2} \mathrm{C}_{4} \mathrm{H}_{4} \mathrm{O}_{6} .2 \mathrm{H}_{2} \mathrm{O}$

\section{Preparation of Lowry's solution}

Solution A, solution B, and solution $\mathrm{C}$ were mixed with a volume:volume ratio of 100:1:1. The solutions were capped and vortexed properly for homogenization.

\section{Preparation of Folin's reagent $(0.1 \mathrm{ml} /$ sample $)$}

A volume of $5 \mathrm{ml}$ of $2 \mathrm{~N}$ Folin and Ciocalteu's phenol reagent was added to $6 \mathrm{ml}$ of distilled water and mixed properly. The resulting solution is sensitive to light. Hence, we prepared it at the last 5 minutes of the first sample incubation and thus stored it in an amber container. The dilution ratio for the Folin and Ciocalteu's phenol reagent was kept at $1: 1$ that resulted in a $1 \mathrm{~N}$ Folin's reagent.

\section{Preparation of antibiotics}

\section{Ampicillin and chloramphenicol}

A composition of $10 \mathrm{mg}$ of antibiotic powder was provided and made it up to $10 \mathrm{ml}$ by sterilized water. This was used as a stock solution to prepare three different concentrations of antibiotics as: $100 \mu \mathrm{l}, 200 \mu \mathrm{l}$, and $1000 \mu \mathrm{l}$.

\section{Statistical analysis}

All the experiments of concentration of protein and absorbance values were conducted. Different concentrations of two antibiotics, ampicillin and chloramphenicol, were used [20]. The mean and degree of freedom were considered for each factor, and one-way ANOVA was used to obtain the results. $p=0.05$ was set as level of significance, and the results were obtained as significant in case of $\mathrm{p}<0.05$ [21].

\section{SPSS logistics}

The frequency table and corresponding bar charts of the comparison table of composition of chick serum to that of different vertebrates were obtained by SPSS logistics software. The accuracy and frequency table of comparison of color produced by serum of different vertebrates were also obtained in a similar manner [22]. The corresponding pie chart of frequencies was plotted in a similar way using IBM SPSS STATISTICS 24 software [23].

\section{Calculations}

Calculations from BSA graph (Graph 1)

From the Beer-Lambert's law, the value of epsilon was calculated. This was done by taking the absorbance and coefficient of BSA sample.

$A=$ Epsilon $*\left\{\mathrm{~L}^{*} \mathrm{C}\right\}$ where Epsilon is absorption coefficient

Slope from the BSA graph: $0.0089 / \mathrm{mg} / \mathrm{Lcm}$

Epsilon=slope $/ \mathrm{L}$

$=0.0089 / \mathrm{mg} / \mathrm{Lcm}$.

Taking this Epsilon value and using the Beer-Lambert's law, the protein concentration of the sample with and without antibiotics was prepared.

\section{RESULTS AND DISCUSSION}

The comparison between the colors of serum of different vertebrates clearly indicates that the color of chick serum is yellow. This is mainly due to the presence of yellow lipochrome (serum lutein) extracted by ethyl alcohol [24] (Table 1).
A comparison between composition of serum and serum proteins of different vertebrates conspicuously indicated that, at identical $\mathrm{pH}$, ionic strength, and dilution, the ionic mobility of chick serum is highest in comparison to other vertebrates. The reason behind high mobility is the presence of high-mobility group proteins isolated from estrogenstimulated chick oviduct [25] (Table 2)

As the concentration of protein increases, the absorption of light by protein also increases linearly. This is in accordance with Beer-Lambert's law and hence its verification; as the concentration of protein increases, the absorption also increases since absorption is directly proportional to concentration according to Beer-Lambert's law (Table 3).

The sample without the addition of antibiotics showed a linear relationship with the concentration of serum (Table 4)

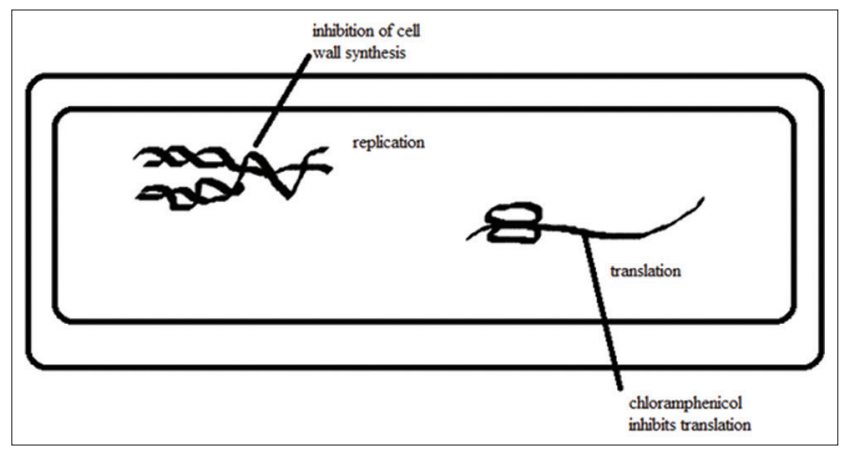

Fig. 1: Action of antibiotics on bacteria

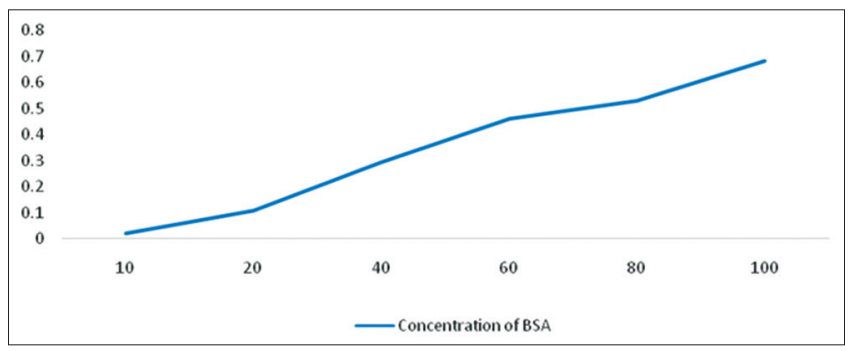

Graph 1: Obtained from values of Table 3: Graph of concentration of bovine serum albumin protein with absorbance values

Table 1: A comparison table between colors produced of serum sample of chick and other vertebrates

\begin{tabular}{ll}
\hline Serum sample & Color produced \\
\hline Chick & Orange red \\
Pigeon & Orange red \\
Dove & Orange red \\
Tortoise & Orange red \\
Toad & Very faint yellow \\
Lizard & Very faint yellow \\
Other vertebrates & Colorless \\
\hline
\end{tabular}

Table 2: Differences in composition of serum in different animals

\begin{tabular}{lllll}
\hline Sample taken & pH & Ionic strength & Dilution & Mobility \\
\hline Human & 7.3 & 0.15 & $1: 3$ & 4.7 \\
Monkey & 7.3 & 0.15 & $1: 3$ & 4 \\
Dog & 7.3 & 0.15 & $1: 3$ & 3.8 \\
Cat & 7.3 & 0.15 & $1: 3$ & 5.3 \\
Chick & 7.3 & 0.15 & $1: 3$ & 6.2 \\
Pigeon & 7.3 & 0.15 & $1: 3$ & 4.4 \\
\hline
\end{tabular}


The major discernment for this effect is that, when the concentration increases, the number of molecules to interact with light also increases, hence increasing the absorption rate with an increase in concentration value (Table 5)

Chloramphenicol antibiotic is bacteriostatic in nature. It inhibits the process of mitochondrial protein synthesis [26]. Addition of this antibiotic on chick serum indicates the role of chloramphenicol on chick serum and also validates Beer-Lambert's law (Table 6).

Ampicillin is a beta-lactam antibiotic which penetrates inside the cell membrane of a bacterial cell. It thus inhibits the growth of bacteria causing cell lysis [27]. Thus, increasing the concentration of antibiotics on chick serum helps us to study the increase or decrease in the concentration of protein present in serum. With increase in the concentration of protein in chick serum, the absorption also increases which gives a range of concentration of protein at which ampicillin acts (Table 7).

The l-erythro isomer of chloramphenicol inhibits the growth of bacteria by blocking protein synthesis [28]. By increasing the concentration of antibiotic, we can interpret the range of serum protein at which antibiotic chloramphenicol acts (Table 8).

Table 3: The values obtained from spectrophotometer by increasing the concentration of protein

\begin{tabular}{ll}
\hline Concentration of protein $(\mathbf{m g} / \mathbf{l})$ & Absorption \\
\hline 10 & 0.021 \\
20 & 0.109 \\
40 & 0.293 \\
60 & 0.463 \\
80 & 0.532 \\
100 & 0.685 \\
\hline
\end{tabular}

Table 4: The different values obtained with increasing concentration of chick serum without the addition of antibiotics with absorption

\begin{tabular}{ll}
\hline Absorption at different concentrations of serum & \\
\hline Concentration of serum (mg/l) & Absorption \\
\hline 10 & 0.991 \\
20 & 1.041 \\
40 & 1.259 \\
60 & 1.362 \\
80 & 1.651 \\
100 & 1.594 \\
\hline
\end{tabular}

Table 5: A comparison between the three different concentrations of antibiotic ampicillin and the absorption values

\begin{tabular}{ll}
\hline Absorption at different concentrations of serum & \\
\hline Concentration of serum (mg/l) & Absorption \\
\hline Concentration of antibiotics: $100 \mu \mathrm{g} / \mathrm{ml}$ & \\
10 & 0.769 \\
20 & 1.340 \\
40 & 1.480 \\
Concentration of antibiotics: $200 \mu \mathrm{g} / \mathrm{ml}$ & \\
10 & 0.683 \\
20 & 1.608 \\
40 & 1.070 \\
Concentration of antibiotics: $1 \mathrm{mg} / \mathrm{ml}$ & \\
10 & 1.467 \\
20 & 1.335 \\
40 & 1.423 \\
\hline
\end{tabular}

The one-way ANOVA results in the addition of ampicillin antibiotic at different concentration showed $\mathrm{p}<0.05$. Thus, we reject the null hypothesis stating that the sum of means is significant with respect to the corresponding $\mathrm{p}$ value. The variation between sample means/ variation within the samples signifying the F-ratio depicts that the variation between the given values of concentration of antibiotic and absorption value is significant [29] (Table 9).

One-way ANOVA test on the values obtained by the concentration of chloramphenicol antibiotic on chick serum showed $\mathrm{p}<0.05$. Thus, we reject the null hypothesis and conclude that the sum of the means is

Table 6: A comparison of three different concentrations of chloramphenicol antibiotic addition on chick serum

\begin{tabular}{ll}
\hline For chloramphenicol & \\
\hline Absorption at different concentrations of serum & \\
\hline Concentration of serum (mg/l) & Absorption \\
\hline Concentration of antibiotics: $100 \mu \mathrm{g} / \mathrm{ml}$ & \\
10 & 1.077 \\
20 & 1.358 \\
40 & 1.630 \\
Concentration of antibiotics: $200 \mu \mathrm{g} / \mathrm{ml}$ & \\
10 & 0.895 \\
20 & 1.560 \\
40 & 1.380 \\
Concentration of antibiotics: $1 \mathrm{mg} / \mathrm{ml}$ & \\
10 & 0.817 \\
20 & 1.380 \\
40 & 1.496 \\
\hline
\end{tabular}

Table 7: A comparison between different concentrations of antibiotic ampicillin and the absorption values

\begin{tabular}{ll}
\hline With antibiotics: For ampicillin & \\
\hline Concentration of protein (mg/l) & Absorption \\
\hline Concentration of antibiotics: $100 \mu \mathrm{g} / \mathrm{ml}$ & \\
86.40 & 0.769 \\
150.56 & 1.340 \\
166.2 & 1.480 \\
Concentration of antibiotics: $200 \mu \mathrm{g} / \mathrm{ml}$ & \\
76.74 & 0.683 \\
180.67 & 1.608 \\
120.22 & 1.070 \\
Concentration of antibiotics: $1 \mathrm{mg} / \mathrm{ml}$ & \\
164.83 & 1.467 \\
150 & 1.335 \\
159.88 & 1.423 \\
\hline
\end{tabular}

Table 8: Different absorption values of serum protein on addition of chloramphenicol

\begin{tabular}{ll}
\hline For chloramphenicol & \\
\hline Concentration of protein $(\mathbf{m g} / \mathbf{l})$ & Absorption \\
\hline Concentration of antibiotics: $100 \mu \mathrm{g} / \mathrm{ml}$ & \\
121.01 & 1.077 \\
152.58 & 1.358 \\
183.14 & 1.630 \\
Concentration of antibiotics: $200 \mu \mathrm{g} / \mathrm{ml}$ & \\
100.56 & 0.895 \\
175.28 & 1.560 \\
155.05 & 1.380 \\
Concentration of antibiotics: $1 \mathrm{mg} / \mathrm{ml}$ & \\
91.7 & 0.817 \\
155.05 & 1.380 \\
168.08 & 1.496 \\
\hline
\end{tabular}


significant. The $\mathrm{F}$ value obtained also depicts that the variance ratio between the given values is significant (Table 10).

The results obtained by the SPSS logistics software showed that the frequencies of the values obtained at different compositions of serum protein are significant (Tables 11 and 12) (Graph 2 and 3).

\section{SERUM COLOR}

The colour of chick, pigeon, dove and tortoise samples produced is orange red whereas that of toad and lizard is very faint yellow. The serum colour of other vertebrates is colourless (Table 1).

\section{CONCLUSION}

Table 13 shows different rates of optical density of proteins present in chick blood serum in addition of different concentrations of the two antibiotics, namely, ampicillin and chloramphenicol. The results obtained by addition of ampicillin and chloramphenicol antibiotics in 10,20 , and $30 \mathrm{mg} / \mathrm{l}$ panoply that, as the concentration of serum increases, the concentration of proteins (without antibiotics) increases significantly. However, it is not observed very linearly in case of $1 \mathrm{mg} / \mathrm{ml}$ ampicillin and $200 \mu \mathrm{g} / \mathrm{ml}$ chloramphenicol antibiotic. This clearly indicates the validation of the Beer-Lambert's law (Table 13). The principle of spectrophotometry and Beer- Lambert's law help us to know the absorbance pattern of proteins in the serum and hence their respective concentrations. This is one of the experiments used in the laboratories at the commercial level to prepare different antibiotics. The rise and fall in the absorbance rate of proteins after addition of different antibiotics represent the increase and decrease in the concentration of proteins, respectively. This shows that every antibiotic acts at a particular concentration on the protein of the serum. Therefore, proper doses of antibiotics are recommended by the doctors.

Table 9: One-way ANOVA results of different concentrations of ampicillin antibiotic

\begin{tabular}{|c|c|c|c|c|c|}
\hline \multicolumn{6}{|c|}{ One-way ANOVA results } \\
\hline Source & df & SS & MS & $\mathbf{F}$ & p value \\
\hline \multicolumn{6}{|c|}{$\begin{array}{l}\text { Concentration of protein in serum with } \\
\text { respective absorbance }\end{array}$} \\
\hline \multicolumn{6}{|c|}{ Without antibiotics } \\
\hline Treatments & 1 & 22371.041 & 22371.041 & 173.8343 & 0.0034 \\
\hline Error & 4 & 514.767 & 128.692 & & \\
\hline Total & 5 & 22885.808 & & & \\
\hline \multicolumn{6}{|c|}{ With antibiotics: For ampicillin } \\
\hline \multicolumn{6}{|c|}{ Concentration of antibiotics: $100 \mu \mathrm{g} / \mathrm{ml}$} \\
\hline Treatments & 1 & 26609.497 & 26609.497 & 29.7590 & 0.0408 \\
\hline Error & 4 & 3576.669 & 894.167 & & \\
\hline Total & 5 & 30186.166 & & & \\
\hline \multicolumn{6}{|c|}{ Concentration of antibiotics: $1 \mathrm{mg} / \mathrm{ml}$} \\
\hline Treatments & 1 & 36892.689 & 36892.689 & 1294.2044 & 0.0002 \\
\hline Error & 4 & 114.024 & 28.506 & & \\
\hline Total & 5 & 37006.714 & & & \\
\hline
\end{tabular}

Table 10: One-way ANOVA results of chloramphenicol antibiotic on chick serum

\begin{tabular}{|c|c|c|c|c|c|}
\hline \multicolumn{6}{|c|}{ For chloramphenicol } \\
\hline Source & df & SS & MS & $\mathbf{F}$ & p-value \\
\hline \multicolumn{6}{|c|}{ Concentration of antibiotics: $100 \mu \mathrm{g} / \mathrm{ml}$} \\
\hline Treatments & 1 & 34150.934 & 34150.934 & 70.7648 & 0.0124 \\
\hline Error & 4 & 1930.391 & 482.598 & & \\
\hline Total & 5 & 36081.325 & & & \\
\hline \multicolumn{6}{|c|}{ Concentration of antibiotics: $200 \mu \mathrm{g} / \mathrm{ml}$} \\
\hline Treatments & 1 & 30395.996 & 30395.996 & 40.6989 & 0.0268 \\
\hline Error & 4 & 2987.400 & 746.850 & & \\
\hline Total & 5 & 33383.396 & & & \\
\hline \multicolumn{6}{|c|}{ Concentration of antibiotics: $1 \mathrm{mg} / \mathrm{ml}$} \\
\hline Treatments & 1 & 28172.272 & 28172.272 & 33.7470 & 0.0345 \\
\hline Error & 4 & 3339.233 & 834.808 & & \\
\hline Total & 5 & 31511.505 & & & \\
\hline
\end{tabular}

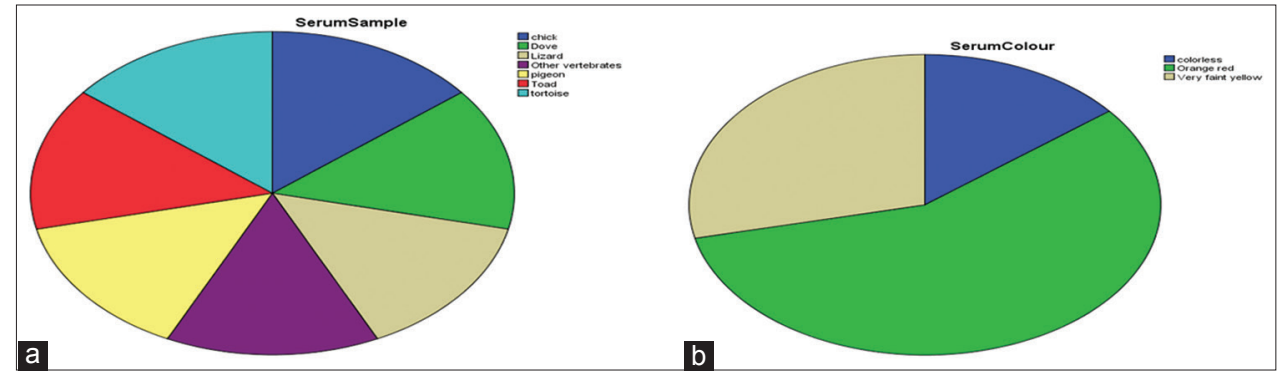

Graph 2: (a and b) The different results of the chick serum comparison of different vertebrates by SPSS logistics software 
Table 11: The different frequencies obtained by the SPSS software of composition of proteins of different vertebrates

\begin{tabular}{|c|c|c|c|c|c|}
\hline Statistics & Mobility & Sample & pH & $\begin{array}{l}\text { Ionic } \\
\text { strength }\end{array}$ & Dilution \\
\hline \multicolumn{6}{|l|}{$\mathrm{N}$} \\
\hline Valid & 6 & 6 & 6 & 6 & 6 \\
\hline Missing & 0 & 0 & 0 & 0 & 0 \\
\hline Mean & 4.7333 & & 7.3000 & 0.1500 & \\
\hline Median & 4.5500 & & 7.3000 & 0.1500 & \\
\hline Mode & $3.80^{\mathrm{a}}$ & & 7.30 & 0.15 & \\
\hline \multicolumn{6}{|c|}{${ }^{a}$ Multiple modes exist. The smallest value is shown } \\
\hline Mobility & Frequency & Percentage & Valid percentage & & Cumulative percentage \\
\hline \multicolumn{6}{|l|}{ Valid } \\
\hline 3.80 & 1 & 16.7 & 16.7 & & 16.7 \\
\hline 4.00 & 1 & 16.7 & 16.7 & & 33.3 \\
\hline 4.40 & 1 & 16.7 & 16.7 & & 50.0 \\
\hline 4.70 & 1 & 16.7 & 16.7 & & 66.7 \\
\hline Total & 6 & 100.0 & 100.0 & & \\
\hline Sample & Frequency & Percentage & Valid percentage & & Cumulative percentage \\
\hline \multicolumn{6}{|l|}{ Valid } \\
\hline Cat & 1 & 16.7 & 16.7 & & \\
\hline Chick & 1 & 16.7 & 16.7 & & 16.7 \\
\hline Dog & 1 & 16.7 & 16.7 & & 33.3 \\
\hline Human & 1 & 16.7 & 16.7 & & 50.0 \\
\hline Monkey & 1 & 16.7 & 16.7 & & 66.7 \\
\hline Pigeon & 1 & 16.7 & 16.7 & & 83.3 \\
\hline Total & 6 & 100.0 & 100.0 & & 100.0 \\
\hline pH & Frequency & Percentage & Valid percentage & & Cumulative percentage \\
\hline \multicolumn{6}{|l|}{ Valid } \\
\hline Ionic strength & Frequency & Percentage & Valid percentage & & Cumulative percentage \\
\hline \multicolumn{6}{|l|}{ Valid } \\
\hline 0.15 & 6 & 100.0 & 100.0 & & 100.0 \\
\hline Dilution & Frequency & Percentage & Valid percentage & & Cumulative percentage \\
\hline \multicolumn{6}{|l|}{ Valid } \\
\hline $1: 3$ & 6 & 100.0 & 100.0 & & 100.0 \\
\hline
\end{tabular}

Table 12: The different results of chick serum comparison of different vertebrates by SPSS logistics software

\begin{tabular}{|c|c|c|c|c|}
\hline Serum sample & Frequency & Percentage & Valid percentage & Cumulative percentage \\
\hline \multicolumn{5}{|l|}{ Valid } \\
\hline Chick & 1 & 14.3 & 14.3 & 14.3 \\
\hline Dove & 1 & 14.3 & 14.3 & 28.6 \\
\hline Lizard & 1 & 14.3 & 14.3 & 42.9 \\
\hline Other & 1 & 14.3 & 14.3 & 57.1 \\
\hline \multicolumn{5}{|l|}{ vertebrates } \\
\hline Pigeon & 1 & 14.3 & 14.3 & 71.4 \\
\hline Toad & 1 & 14.3 & 14.3 & 85.7 \\
\hline Tortoise & 1 & 14.3 & 14.3 & 100.0 \\
\hline Total & 7 & 100.0 & 100.0 & \\
\hline Serum color & Frequency & Percentage & Valid percentage & Cumulative percentage \\
\hline \multicolumn{5}{|l|}{ Valid } \\
\hline Colorless & 1 & 14.3 & 14.3 & 14.3 \\
\hline Orange red & 4 & 57.1 & 57.1 & 71.4 \\
\hline $\begin{array}{l}\text { Very faint } \\
\text { yellow }\end{array}$ & 2 & 28.6 & 28.6 & 100.0 \\
\hline Total & 7 & 100.0 & 100.0 & \\
\hline
\end{tabular}




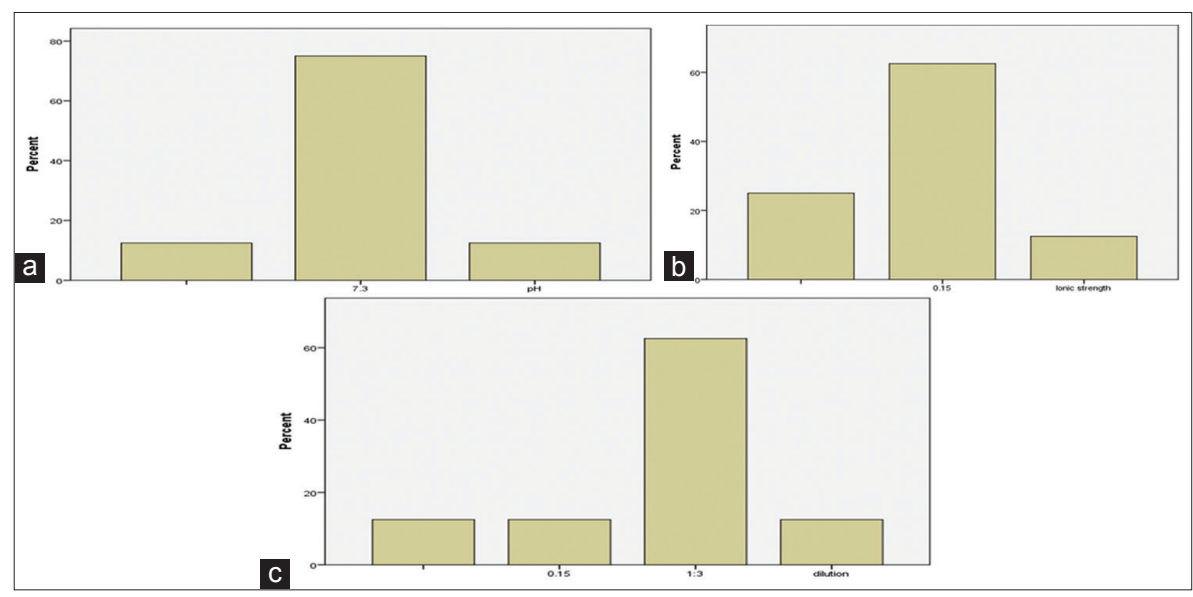

Graph 3: (a-c) The different frequencies obtained by the SPSS software of composition of proteins of different vertebrates

Table 13: Summary of the results obtained by the concentration of serum protein (without antibiotics) and concentration of protein with ampicillin and chloramphenicol

\begin{tabular}{|c|c|c|c|c|c|c|c|}
\hline \multirow{3}{*}{$\begin{array}{l}\text { Concentration of } \\
\text { serum }(\mathrm{mg} / \mathrm{l})\end{array}$} & \multirow{3}{*}{$\begin{array}{l}\text { Concentration of protein (without } \\
\text { antibiotics)(mg/l) }\end{array}$} & \multicolumn{6}{|c|}{ Concentration of protein (with antibiotics) (mg/l) } \\
\hline & & \multicolumn{3}{|l|}{ Ampicillin } & \multicolumn{3}{|c|}{ Chloramphenicol } \\
\hline & & $100 \mu \mathrm{g} / \mathrm{ml}$ & $200 \mu \mathrm{g} / \mathrm{ml}$ & $1 \mathrm{mg} / \mathrm{ml}$ & $100 \mu \mathrm{g} / \mathrm{ml}$ & $200 \mu \mathrm{g} / \mathrm{ml}$ & $1 \mathrm{mg} / \mathrm{ml}$ \\
\hline 10 & 111.3 & 86.40 & 86.40 & 164.83 & 121.01 & 100.56 & 91.7 \\
\hline 20 & 116.9 & 150.56 & 150.56 & 150 & 152.58 & 175.28 & 155.05 \\
\hline 40 & 141.46 & 166.2 & 166.2 & 159.88 & 183.14 & 155.05 & 168.08 \\
\hline
\end{tabular}

\section{ACKNOWLEDGMENTS}

We would like to take this opportunity to thank VIT University for encouraging project-based learning and giving us the opportunity to perform this research. We would also like to express our sincere gratitude to our honorable Chancellor Dr. G. Viswanathan and Vice presidents Dr. Sekar Viswanathan and Mr. G.V. Selvan for constant motivation and help. The School of Biosciences and Technology had equipped us with all the reagents and materials in their laboratories which we required in our work.

\section{REFERENCES}

1. Meti MD, Nandibewoor ST, Joshi SD, More UA, Chimatadar SA. Multispectroscopic investigation of the binding interaction of fosfomycin with bovine serum albumin. J Pharm Anal 2015;5(4):249-55.

2. Porwal PK. The effect of metformin on non-enzymatic glycosylation of recombinant human serum albumin. Int J Pharm Pharm Sci 2016;8(8):208-14.

3. Kirthika P, Dheeba B, Sivakumar R, Abdulla S. Plant mediated synthesis and characterisation of silver nanoparticles. Int J Pharm Pharm Sci 2014;6(8):304-10.

4. Buddanavar AT, Nandibewoor ST. Multi-spectroscopic characterization of bovine serum albumin upon interaction with atomoxetine. J Pharm Anal 2016; J Pharm Anal 2016;7(3):1-8.

5. Suryawanshi VD, Walekar LS, Gore AH, Anbhule PV, Kolekar GB. Spectroscopic analysis on the binding interaction of biologically active pyrimidine derivative with bovine serum albumin. J Pharm Anal 2016;6(1):56-63

6. Li Y, Yang G, Mei Z. Spectroscopic and dynamic light scattering studies of the interaction between periodontics acid and bovine serum albumin. Acta Pharm Sin B 2012;2(1):53-9.

7. Yang GD, Li C, Zeng AG, Zhao Y, Yang R, Bian XL. Fluorescence spectroscopy of osthole binding to human serum albumin. J Pharm Anal 2013;3(3):200-4.

8. Redmile-Gordon MA, Armenise E, White RP, Hirsch PR, Goulding KW. A comparison of two colorimetric assays, based upon Lowry and Bradford techniques, to estimate total protein in soil extracts. Soil Biol Biochem 2013;67(100):166-73.

9. Lee N, Shin S, Chung HJ, Kim DK, Lim JM, Park H, et al. Improved quantification of protein in vaccines containing aluminum hydroxide by simple modification of the Lowry method. Vaccine 2015;33(39):5031-4.

10. Oftedal OT, Eisert R, Barrell GK. Comparison of analytical and predictive methods for water, protein, fat, sugar, and gross energy in marine mammal milk. J Dairy Sci 2014;97(8):4713-32.

11. Bishwambhar M, Suneetha V. The microbial pullulan as therapeutic tool in medicine. Int J Ayurveda Herbal Med 2012;2(1):180-6.

12. Dias-Souza MV, Soares DL, dos Santos VL. Comparative study of free and liposome-entrapped chloramphenicol against biofilms of potentially pathogenic bacteria isolated from cooling towers. Saudi Pharm J 2017;25(3):359-64.

13. Zhang J, Chen L, Zeng B, Kang Q, Dai L. Study on the binding of chloroamphenicol with bovine serum albumin by fluorescence and UV-vis spectroscopy. Spectrochim Acta A Mol Biomol Spectrosc 2013;105:74-9.

14. Cheng Z, Liu R, Jiang X. Spectroscopic studies on the interaction between tetrandrine and two serum albumins by chemometrics methods. Spectrochim Acta A Mol Biomol Spectrosc 2013;115:92-105.

15. Wesierska E, Saleh Y, Trziszka T. Antimicrobial activity of chicken egg white cystatin. World J Microbiol Biotechnol 2005;21:59-64.

16. Jones M, Denieffe S, Griffin C, Tinago W, Fitzgibbon MC. Evaluation of cystatin $\mathrm{C}$ in malignancy and comparability of estimates of GFR in oncology patients. Pract Lab Med 2017;7:36-40.

17. Slocombe SP, Ross M, Thomas N, McNeill S, Stanley MS. A rapid and general method for measurement of protein in micro-algal biomass. Bioresour Technol 2013;129:51-7.

18. Kumari M, Asthir B. Transformation of sucrose to starch and protein in rice leaves and grains under two establishment methods. Rice Sci 2016;23(5):255-65.

19. Rover MR, Brown RC. Quantification of total phenols in bio-oil using the folin-ciocalteu method. J Anal Appl Pyrolysis 2013;104:366-71.

20. Ahmed AN, Rashed HM. ANOVA modeling on sintering parameters and frequencies, affecting microstructure and dielectric constant of $\mathrm{Nb}$ doped $\mathrm{BaTiO}_{2}$. Proc Eng 2014;90:72-7.

21. Kumar M, Rath NK, Swain A, Rath SK. Feature selection and classification of microarray data using mapreduce based ANOVA and K-nearest neighbor. Proc Comput Sci 2015;54:301-10.

22. Mahapoonyanont N, Mahapoonyanont T, Pengkaew N, Kamhangkit R. Power of the test of one-way ANOVA after transforming with large sample size data. Proc Soc Behav Sci 2010;9:933-7.

23. Ting H, Liangen Z, Yan Z, Chuanying Z, Jing L. Water quality comprehensive index method of Eltrix river in Xin Jiang province using 
SPSS. Proc Earth Planet Sci 2012;5(2011):314-21.

24. Suneetha V, Bishwambhar M, Gopinath R, Shrestha SR, Kartik GK, Pravesh C, et al. Screening and identification of degradable products by pectin lyase producing actinomycetes from katpadi and chittoor fruit industrial waste enriched soil samples. Asian J Microbiol Biotechnol Environ Sci 2012;14(2):405-12.

25. Zeweil HS, Rizk RE, Bekhet GM, Ahmed MR. Comparing the effectiveness of egg disinfectants against bacteria and mitotic indices of developing chick embryos. J Basic Appl Zool 2015;70:1-15.

26. Verma SK, Lal M, Das MD. Optimisation of process parameters for production of antimicrobial metabolites by an endophytic fungus aspergillus sp. CPR5 isolated from Calotropis procera root. Asian J Pharm Clin Res 2017;10(4):225-30.

27. Khan AA, Mohd A, Bano S, Siddiqi KS, Asiri AM. Spectrophotometric methods for the determination of ampicillin by potassium permanganate and 1-chloro-2, 4-dinitrobenzene in pharmaceutical preparations. Arab J Chem 2015;8(2):255-63.

28. Liu M, Liu Y, Cheng Z, Liu J, Chai T. Effects of chromic chloride on chick embryo fibroblast viability. Toxicol Rep 2015;2:555-62.

29. Yusnita MA, Paulraj MP, Yaacob S, Nor-Fadzilah M, Shahriman AB. Acoustic analysis of formants across genders and ethnical accents in Malaysian English using ANOVA. Proc Eng 2013;64:385-94. 